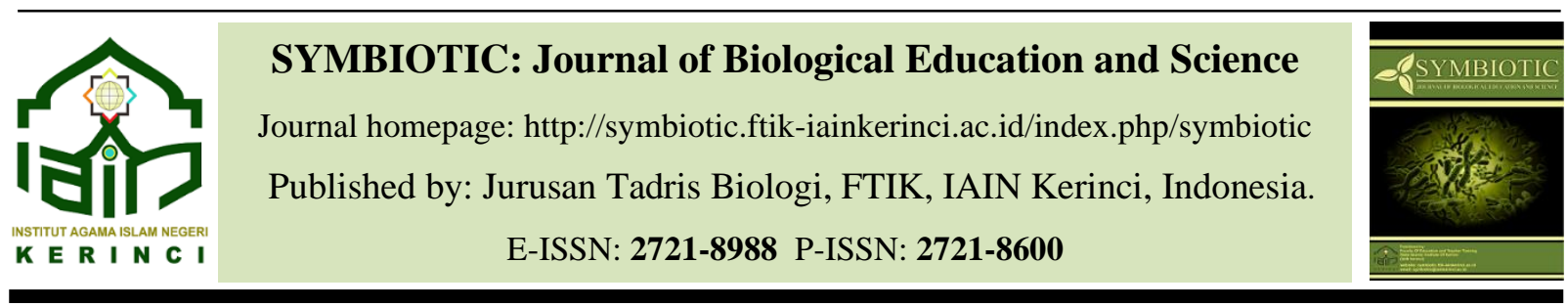

\title{
Etnobotani Familia Zingebaraceae (Suku Jahe-Jahean) di Desa Koto Dua Lama Kecamatan Air Hangat Kabupaten Kerinci
}

\author{
Novinovrita. $\mathbf{M}^{\mathbf{1}}$, Bony Irawan ${ }^{2}$ \\ ${ }^{1}$ Institut Agama Islam Negeri Kerinci, Sungai Penuh, Jambi \\ ${ }^{2}$ Universitas Martitim Raja Ali Haji, Tanjung Pinang, Kepulauan Riau \\ e-mail korespondensi : novibio3@gmail.com
}

\begin{abstract}
Zingiberaceae belongs to the Spermatophyta division, Angiospermae sub division, Liliopsida class, Zingiberidae sub class, Zingiberales order. Zingiberaceae is a plant with habitus in the form of perennial herbs that are aromatic. Zingiberaceae is a basic plant from tropical forests which is found in many shady places and valleys, sometimes also found in secondary forests. In Koto Dua Lama village, many species of Zingiberaceae are found, but have not been inventoried or reported scientifically. This study aims to diversify zingiberacaeae species found in the village of Koto Dua Lama. This type of research is qualitative research. In this study exploratory survey methods were used. The techniques used in collecting data are observation and collection of plants and documentation. In this study 11 species of Zingiberaceae were included in 8 genus and 2 sub-families including Costus speciosus (Sitawa), Alpinia galanga (Lengkueh), Amomum cardomomum (gandan bumbu), Curcuma domestica (kunyit), Curcuma mango (kunyit temu), Curcuma xanthorrhiza (Temulawak), Etlingera elatior (Sabung), Hedychium coronarium (Suli), Kaemferia galanga (Ceku), Zingiber Cassumnar (Kunyit Melai) and Zingiber Officinale (padipadi). Each type has its own description or characteristics.
\end{abstract}

Keywords: Zingiberaceae, inventory, description

\begin{abstract}
ABSTRAK
Zingiberaceae termasuk ke dalam divisi Spermatophyta, sub divisi Angiospermae, kelas Liliopsida, sub kelas Zingiberidae, ordo Zingiberales. Zingiberaceae merupakan tumbuhan dengan habitus berupa herba perennial yang aromatis. Zingiberaceae merupakan tumbuhan dasar dari hutan tropis yang banyak ditemukan tumbuh di tempat rindang dan lembah, kadangkadan gjuga ditemukan di hutan sekunder. Di desa Koto Dua Lama, banyak ditemukan jenisjenis Zingiberaceae, tetapi belum diinventarisasi atau dilaporkan secara ilmiah. Penelitian ini bertujuan untuk mengiventarisasi jenis-jenis zingiberacaeae yang terapat di desa Koto Dua Lama. Jenis penelitian ini adalah penelitian kualitatif. Dalam penelitian ini digunakan metode survei eksploratif. Adapun teknik yang digunakan dalam pengumpulan data adalah observasi dan koleksi tanaman serta dokumentasi. Dalam penelitian didapatkan 11 jenis Zingiberaceae yang termasuk ke dalam 8 genus dan 2 sub famili diantaranya Costus speciosus, (Sitawa), Alpinia galanga (Lengkueh), Amomum cardomomum (gardan bumbu)), Curcuma domestica (kunyit), Curcuma mangga (Kunyit temu), Curcuma xanthorrhiza (Temulawak), Etlingera elatior (Sabung), Hedychium coronarium (Suli), Kaemferia galanga (Ceku), Zingiber Cassumnar (Kunyit Melai) dan Zingiber Officinale (padi-padi). Masing-masing jenis memiliki deskripsi atau karateristik tersendiri.
\end{abstract}

Kata Kunci : Zingiberaceae, inventarisasi, deskripsi. 


\section{PENDAHULUAN}

Zingiberaceae termasuk ke dalam divisi Spermatophyta, subdivisi Angiospermae, kelas Liliopsida, sub kelas Zingiberidae, ordo Zingiberales (Rideng, 1989). Larsen at al. (1999) menyatakan ordo Zingiberales mempunyai 8 famili yaitu Musaceae, Lowiaceae, Heliconiaceae, Strelitziaceae, Zingiberaceae, Costaceae, Cannaceae, dan Maranthaceae. Dua famili terbesar adalah Zingiberaceae dan Marantaceae, dimana daerah penyebaran keduanya berbeda Zingiberaceae tersebar di daerah Tropis Asia dan Marantaceae di daerah tropis Amerika (Larsen et al., 1999). Sedangkan Smith (1981) menyatakan famili Zingiberaceae terdiri atas dua sub famili yaitu Zingiberoidae dan Costoideae, dimana Zingiberideae terdiri atas 4 tribe yaitu Globbeae, zingiberae, Hedychieae dan Alpineae.

Zingiberaceae merupakan tumbuhan dengan habitus berupa herba perennial yang aromatis (Syamsuardi, Tamin dan Nurainas, 2006). Batang membentuk rizoma, biasanya berdaging, percabangan simpodial, setiap bagian dari percabangan diakhiri dengan kuncup daun tegak atau sesekali kuncup bunga saja. Bagian rizoma yang mendatar diliputi sisik. Percabangan utama biasanya datar tersusun dari cabang yang menyebar ke segala arah (Holttum, 1950). Ditambahkan oleh Wu dan Larsen (2000), rizoma berdaging ada yang menyerupai tuber ada yang tidak, kadang disertai akar yang membentuk tuber. Batang biasanya pendek dan digantikan oleh batang semu yang dibentuk oleh vagina.

Daun Zingiberaceae merupakan daun tunggal yang tersusun berselang-seling dengan vagina daun terbuka, biasanya terdapat ligula, ada yang punya petiolus ada yang tidak, terdapat antara lembaran daun dengan vagina, lembaran daun suborbikularis atau lanceolatus, menggulung secara longitudinal pada kuncup. Glabrous atau berambut, ibu tulang daun jelas, pertulangan daun lateral biasanya banyak dan tersusun menyirip sejajar, pinggir daun rata (Wu dan Larsen, 2000). Syamsuardi et al. (2006), menambahkan bahwa daun berpelepah (juga membentuk batang semu), lamina menggulung waktu muda.

Bunga merupakan bunga majemuk terminal pada batang semu atau terpisah sendiri yakni keluar dari dasar batang semu atau keluar dari rizoma. Bunga tersusun dalam kelompok. Bunga mekar biasanya bertahan satu hari atau kurang (Holtum, 1950). Wu dan Larsen (2000), menambahkan bahwa bunga dibungkus daun pelindung, berbentuk silindris atau fusiform kadang globosus punya sangat sedikit hingga sejumlah besar braktea yang tersusun rapat dan berwarna. Bunga biseksual, epiginus, zigomorphus. Calyx berbentuk tabung tipis dan terpisah pada satu sisi kadang menyerupai spatha. Korola tepat menyerupai tabung, punya tiga lobus distal, ukuran dan bentuk lobus bervariasi.

Stamen atau staminodia ada enam tersusun dalam dua lingkaran. Dua staminodia lateral dibagian lingkaran luar yang menyerupai petal, atau membentuk gigi halus pada dasar dari labellum atau adnatus terhadap labellum, atau tidak ada. Staminodia tengah dari lingkaran luar selalu mengalami penyusutan. Labellum dibentuk oleh dua staminodia lateral dari lingkaran dalam. Stamen fertil terletak di tengah lingkaran dalam, tingkat stamen panjang atau pendek lokus antera ada dua, 
melengkung ke dalam, matang dengan membentuk pori panjang, pembuluh penghubung sering meluas kearah basis dari sayap dan atau pada bagian celah ujung. Ovari inferior, selalu mempunyai tiga lokus, satu atau tiga lokus ketika matang, stigma muncul diatas antera berbentuk funel atau papilosus, agak basah, pinggirnya sering bersilia. Stilus dua, menyusut pada kelenjar nektar dibagian apeks ovari (Wu dan Larsen, 2000).

Buah biasanya "dehiscent" berbentuk kapsul atau berdaging atau ada juga yang "indehiscent" dengan dinding yang sangat tipis pecah secara bertahap setelah tua. Biji biasanya berarillus, kadangkadang menutup biji secara keseluruhan sebagian saja atau pada bagian dasarnya saja (Holttum, 1950). Wu dan Larsen (2000) menambahkan bahwa biji berjumlah mulai dari sedikit hingga beberapa (banyak) arilus.

Zingiberaceae merupakan tumbuhan dasar dari hutan tropis yang banyak ditemukan tumbuh di tempat rindang dan lembah, juga kadang-kadang ditemukan di hutan sekunder. Beberapa jenis dapat bertahan hidup di tempat terbuka dan tumbuh pada kemiringan yang tinggi (Sirirugsa, 1999). Selanjutnya Holttum (1950), menyatakan bahwa kebanyakan Zingiberaceae tumbuh di daerah lembah, beberapa dari jenis ini hanya ditemukan pada tempat lembah. Zingiberaceae hidup melimpah pada daerah dataran rendah atau pada sisi bukit, sangat sedikit sekali terlihat pada daerah pegunungan tinggi.

Jumlah jenis yang telah dilaporkan terus mengalami perubahan dan peningkatan setiap tahunnya. Holttum (1950), menyatakan bahwa Zingiberaceae yang terdiri dari 47 genus dengan 1000 jenis tersebar di Asia Tropis, Afrika, dan Amerika dan 160 jenis dari 23 genus terdapat di Semenanjung Malaya. Sedangkan Woodland (1997) menyatakan 45 sampai 50 genus dengan 1000 sampai 1300 jenis tersebar di daerah tropis Afrika dan dari Asia ke Pasifik. Selanjutnya Sirirugsa (1999) menyatakan daerah terkaya akan jenis dari famili ini adalah kawasan Malesiana, yaitu Indonesia. Malaysia, Singapura, Brunei, Filipina dan Papua New Ginia, terdapat lebih kurang 600 jenis dan 24 genus. Selanjutnya Larsen et al. (1999) menyatakan bahwa famili Zingiberaceae terdiri dari lebih kurang 1200 jenis dengan 1000 diantaranya tersebar di daerah Tropis dan ditemukan 204 jenis dengan 20 genus di daerah Malaysia dan Singapura.

Jumlah dan distribusi jenis Zingiberaceae di Sumatera juga telah dilaporkan dimana Miquel (1862) yang menyatakan bahwa di sumatera terdapat 29 jenis Zingiberaceae. Selanjutnya Newman et al. (2004) dalam 'Checklist of the Zingiberaceae of Malesia' mencatat 76 jenis Zingiberaceae di Sumatera yang antara lain dikoleksi dari Sumatera Utara, Sumatera Selatan, Riau dan Sumatera Barat.

Desa Koto Dua Lama merupakan sebuah desa yang terdapat di kecamatan Air Hangat, dahulu desa ini disebut kampung Koto Dua. Desa Koto Dua Lama dikelilingi oleh hamparan persawahan rakyat yang menjadi sumber utama ekonomi masyarakat yaitu pertanian. Sebelah utara terdapat aliran sungai kecil yang amat jernih yang dalam bahasa daerahnya disebut "Air Muhut" artinya air semurup berasal dari aliran air terjun perbukitan Pendung Semurup dan saat ini menjadi sumber utama bagi PDAM Tirta Sakti Kerinci mengabil Air Jernih untuk kebutuhan masyarakat Kerinci umumnya dan 
kecamatan Air Hangat khususnya, disetiap halaman rumah penduduk terdapat satu batang pohon pinang sebagai pohon pelindung sekaligus menjadikan desa ini sejuk dipandang mata. Selain itu, di sebelah utara terlihat juga puncak Gunung Kerinci, serta Bukit Pendung dimana bukit tersebut dijadikan oleh masyarakat untuk bercocok tanam kayu manis, cengkeh, kopi, jahe-jahean dan tanaman palawija lainnya untuk memenuhi kebutuhan ekonomi masyarakat.

Umumnya tanaman yang mereka budidayakan oleh masyarakat Koto Dua Lama digunakan untuk kebutuhan sehari-hari seperti untuk makanan, sayuran, maupun obat-obatan, selain dijual untuk pendapatan ekonomi keluarga. Dari beberapa tumbuhan yang mereka tanam baik di sekitar pekarangan, ataupun di ladang banyak ditemukan tumbuhan yang termasuk kedalam kelompok jahejahean, seperti jahe, kunyit dan jenis lain. Sampai saat ini belum ada laporan secara ilmiah apa saja jenis-jenis jahe yang terdapat di Desa Koto Dua Lama, berdasarkan hal tersebut penulis ingin menginventarisasi secara ilmiah apasaja jenis-jenis Zingiberaceae yang terdapat di desa Koto Dua Lama dengan melakukan penelitian yang berjudul "Inventarisasi Jenis-Jenis Zingebaraceae (Keluarga Jahe_Jahean) Di Desa Koto Dua Lama Kecamatan Air Hangat Kerinci.

\section{METODE}

Jenis penelitian ini adalah penelitian kualitatif dengan metode survei eksploratif. Adapun teknik yang digunakan dalam pengumpulan data adalah Observasi dan koleksi tanaman serta dokumentasi.

\section{Observasi dan Koleksi Tanaman}

Dalam studi ini hal pertama yang dilakukan adalah observasi dan pengkoleksian semua jenis Zingiberaceae yang tumbuh, baik yang dimanfaatkan maupun liar yang terdapat di Desa Koto Dua Lama. Koleksi ini dibutuhkan sebagai bahan untuk wawancara, spesimen dan bahan identifikasi. Zingiberaceae mempunyai habitus yang berbeda-beda dari jenis tumbuhan pada umumnya, maka diperlukan cara pengkoleksian khusus. Untuk kelompok Zingiberaceae yang berukuran kecil (maksimal tinggi 1 meter) dikoleksi semua organ. Sedangkan untuk kelompok yang berukuran besar ( $>1$ meter ) dilakukan cara pengkoleksian sebagai berikut:

1) Untuk organ vegetatif dibuat berdasarkan letak daun yakni potongan daun bagian bawah, daun bagian bawah, daun bagian tengah, dan daun bagian atas.

2) Ligula harus tetap utuh

3) Untuk organ genustif, bunga majemuk keluar langsung dari rizoma, usahakan bunga majemuk tetap melekat pada rizoma. Buah usahakan tetap melekat pada buah majemuk

Selain itu dilakukan pengambilan foto dari masing-masing jenis yang didapatkan dengan menggunakan kamera. 


\section{Dokumentasi}

Selanjutnya koleksi tumbuhan ini dibawa ke laboratorium dan dilakukan pembuatan spesimen herbarium dimana proses pembuatan spesimen herbarium dilaksanakan mulai dari pengkoranan, pengovenan, pemontingan dan pelabean. Selanjutnya spesimen diidentifikasi dengan menggunakan spesimen herbarium yang telah teridentifikasi, kunci determinasi, deskripsi, monograf dan gambar deskriptif yang merujuk pada literatur atau buku acuan yang terkait. Selanjutnya voucer speciemen disimpan di Laboratorium IAIN Kerinci.

\section{HASIL DAN PEMBAHASAN}

Pada penelitian ini diketahui bahwa di desa Koto Dua Lama didapatkan beberapa jenis Zingiberaceae, seperti terlihat pada tabel dibawah ini

Tabel 1: Jenis-jenis Zingiberaceae yang didapatkan di Desa Koto Dua Lama

\begin{tabular}{|c|c|c|c|c|}
\hline No & Sub Familia & Genus & Nama Spesies & Nama Lokasi \\
\hline 1 & Costoideae & Costus & Costus Speciosus (Koen).) J.E Smith & Stawa \\
\hline 2 & \multirow{10}{*}{ Zingiberoideae } & Alpinia & Alpinia galanga $\mathrm{Sw}$ & Lengkueh \\
\hline 3 & & Атотит & Amomum cardomoтит $\mathrm{L}$. & $\begin{array}{l}\text { Gardan } \\
\text { bumbu }\end{array}$ \\
\hline 4 & & \multirow{3}{*}{ Curcuma } & Curcuma domestica Val. & Kunyit \\
\hline 5 & & & Curcuma mangga Val. & Kunyit Temu \\
\hline 6 & & & Curcuma xanthorrhiza Roxb. & Temu lawak \\
\hline 7 & & Etlingera & Etlingera elatior (Jack) R.M. Sm & Sabung \\
\hline 8 & & Hedychium & Hedychium coronarium Koen. & Suli \\
\hline 9 & & Kaempferia & Kaempferia galanga $\mathrm{L}$. & Ceku \\
\hline 10 & & \multirow{2}{*}{ Zingiber } & Zingiber cassumnar Roxb. & Kunyit Melai \\
\hline 11 & & & Zingiber officinale Rosc & padi-padi \\
\hline
\end{tabular}

Berdasarkan tabel diatas dapat dilihat bahwa di daerah Desa Koto Dua Lama didapatkan 11 jenis Zingiberaceae yang termasuk ke dalam 8 genus dan 2 sub famili. Sub famili Costoideae hanya terdiri atas satu genus yaitu sedangkan sub famili Zingiberoideae terdiri dari 8 genus yaitu Alpinia, Amomum, Curcuma, Etlingera, Costus, Hedychium, Hornstedtia, Kaempferia, dan Zingiber. Genus yang paling banyak dimanfaatkan yaitu Curcuma dan Zingiber, yang masing-masingnya terdiri dari 3 dan 2 jenis. Enam genus lainnya hanya terdiri dari 1 jenis saja yang dimanfaatkan oleh masyarakat. Jenis-jenis yang dimanfaatkan tersebut adalah Costus speciosus, (Sitawa), Alpinia galanga (Lengkueh), Amomum cardomomum (gardan bumbu)), Curcuma domestica (kunyit), Curcuma mangga (Kunyit temu), Curcuma xanthorrhiza (Temulawak), Etlingera elatior (Sabung), Hedychium coronarium (Suli), Kaemferia galanga (Ceku), Zingiber Cassumnar (Kunyit Melai) dan Zingiber Officinale (padi-padi).

Jumlah jenis yang ditemukan ini lebih sedikit dibandingkan dengan jumlah jenis yang ditemukan di Sumatera seperti yang telah dilaporkan sebelumnya dimana Miquel (1862) yang menyatakan bahwa di Sumatera terdapat 29 jenis Zingiberaceae. Selanjutnya Newman et al. (2004) 
dalam 'Checklist of the Zingiberaceae of Malesia' mencatat 76 jenis Zingiberaceae di Sumatera yang antara lain dikoleksi dari Sumatera Utara, Sumatera Selatan, Riau dan Sumatera Barat. Hal ini mungkin disebabkan daerah penelitiaannya yang cukup luas yaitu paa beberapa daerah di Sumatera lainnya.

Jenis-Jenis Zingiberaceae yang didapatkan ini dapat dibagi menjadi kelompok tumbuhan budidaya dan tumbuhan liar. Jenis yang termasuk tumbuhan budidaya terdiri dari 8 jenis seperti $A$. Galangga, A. Cardomomum, C. Domestica, C. Mangga, C. Xanthorrhiza, K. Galanga dan Z. Officinale. Umumnya jenis-jenis ini dibudidayakan di sekitar pekarangan rumah dan ladang masyarakat. Jenis yang termasuk tumbuhan yang masih liar terdiri dari 4 seperti $C$. spesiosus, E. Megalocheilos. H. Coronarium, H. Elongata. umumnya jenis-jenis ini tumbuh liar dipinggir sungai, pinggir jalan dan pinggir hutan. Selain itu terdapat tiga jenis yang termasuk tanaman budidaya, tetapi termasuk juga tumbuhan liar seperti C. Speciosus, E. Elatior dan Z. Cassumnsr. Perbandinagn jumlah jenis yang termasuk tumbuhan budidaya, tumbuhan liar serta sudah dibudidayakan tapi masih tumbuh liar.

Jenis budidaya lebih banyak dibandingkan dengan jenis yang masih liar, ini mengindikasikan bahwa masyarakat telah mempunyai usaha untuk mempertahankan keberadaan jenis-jenis ini atau berperan dalam upaya konservasi jenis-jenis Zingiberaceae yang dimanfaatkan, hasil ini hampir sama dengan penelitian Sathyami yang menyatakan hampir 40\% tumbuhan obat telah dibudidayakan oleh penduduk Desa Koto Dua Lama, jadi penduduk tidak hanya menggantungkan keperluan tumbuhan sepenuhnya dari apa yang ada di alam. Upaya pembudidayaan tumbuhan obat untuk keperluan seharihari ini menunjukkan bahwa penduduk desa koto dua lama masih sangat peduli dengan upaya mempertahankan ketersediaan tumbuhan-tumbuhan yang mereka manfaatkan dalam kehidupan seharihari.

Berdasarkan hasil pengamatan langsung, jenis-jenis Zingiberaceae juga diperjual belikan di pasar tradisional setempat, seperti A. cordomomum, A. galanga, C. domestica, E.elatior, K.galanga, Z. officinale dan Zingiber sp., selain itu menurut beberapa informan beberapa tahun yang lalu jenis $\mathrm{Z}$. officinale pernah dibudidayakan secara besar-besaran dikarenakan mahalnya harga rizoma jenis ini. Jadi dari hasil ini dapat dilihat bahwa jenis-jenis Zingiberaceae ini berperan juga dalam meningkatkan perekonomian masyarakat setempat,

Berdasarkan hasil observasi langsung di lokasi penelitian, masing-masing jenis memiliki deskripsi atau karakteristik tersendiri. Adapun deskripsi dari masing-masing jenis tersebut adalah :

1. Costus Spesiosus (Koen.) J.M Smith ; Backer C. A dan R.C Bakhuizen Jr Van den brink, 1968, Flora of Java, Vol. III, 75-76

\section{Sinonim \\ : Costus sericeous $\mathrm{B} 1$ \\ Nama Daerah $\quad$ : Sitawa}

Tumbuhan ini berupa herba, tinggi 0,50-3,5 m, batang lunak, beruas-ruas, licin, ditutupi oleh pelepah daun dan biasanya bercabang. Daun tunggal, berdaging, berbentuk lanset memanjang 
dengan pangkal tumpul pinggir rata dan ujung daun meruncing, panjang 13-19,5 $\mathrm{cm}$ dan lebar 7,5$9 \mathrm{~cm}$. Bunga majemuk muncul pada ujung batang berwarna merah. Tumbuhan ini biasanya tumbuh di pinggir hutan, pinggir jalan atau biasanya ditanam di sekitar perkarangan rumah penduduk. Manjang menyatakan tumbuhan ini mengandung senyawa alkaloid.

2. Alpina galanga Sw. ; Hooker (1967) Flora of British india : vol 6 hal 253: Ridley (1967) The Flora of malay Peninsula : Vol IV hal 279: Larsen et al (1999) Ginger of peninsular Malaysia and singapore: hal $58 \& 66$.

$\begin{array}{ll}\text { Sinonim } & \text { : Languas galanga }(\mathrm{L} .) \\ \text { Nama daerah } & : \text { Lengkueh }\end{array}$

Tumbuhan ini berumpun, dengan tinggi 2-3m. Rizoma simpodial, diameter 1,5-2,5 $\mathrm{cm}$, puth krem. Daun berambut pendek, terutama bagian yang dekat dengan pelepah; tangkai daun panjangnya 5-7 mm, berambut pada permukaan bawah; lembaran daun elips-lanset, panjang 45-50 $\mathrm{cm}$, lebar 9-11 cm, pangkal daun menyempit, ujung daun runcing. Bunga majemuk muncul pada ujung batang, berwarna hijau muda. Jenis ini biasanya ditanam disekitar pekarangan rumah atau kebun penduduk.

3. Amomum cardomomum L. ; Backer C.A dan R.C Bakhuizen Jr Van Den Brink, 1968, Flora of Java, vol. III. 49.

Sinonim : Amomum capulaga Sp. Et Burk

Nama Daerah : : Gardamunggu

Tumbuhan ini berupa herba, tinggi 1-1,5 m, daun tunggal, memeluk batang, tersusun berselang-seling, helaian daun berbentuk pita, atau lanset dengan pangkal dan ujung yang runcing, pinggir rata, panjang 10-23 $\mathrm{cm}$ dan lebar 5-7 $\mathrm{cm}$. Bunga majemuk berupa bulir dan muncul dari rizoma. Buah berupa buah kendaga berbentuk bulat telur berwarna kuning keabuan. Wijayakusuma (1996), menyatakan tumbuhan ini mengandung senyawa terpineol, terpinal asetat, sineol, berneol, protein dan minyak atsiri.

4. Curcuma domestica Val, ; Backer, C.A dan R.C. Bakhuizen Jr Van den Brink, 1968, Flora of Java, Vol. III, 72.

$\begin{array}{ll}\text { Sinonim } & \text { : Curcuma longa sensu Val., non L. } \\ \text { Nama daerah } & \text { : Kunyit }\end{array}$

Tumbuhan ini berupa herba, tinggi $70-80 \mathrm{~cm}$, memiliki batang semu yang dibentuk oleh pelepah daun. Rizoma induk berdaging yang membentuk anak-anakan rizoma yang lebih panjang dan langsing, berwarna kuning jingga. Daun tunggal, bertangkai panjang dan ujung runcing, pinggir rata, panjang 20-40 cm. Dan lebar 8-12 cm, berwarna hijau. Bunga majemuk, muncul dari rizoma yang berbatang pendek, daun pelindung seperti sisik dan bunga berwarna kuning pucat atau 
putih. Tumbuhan ini biasanya ditanam disekitar perkarangan rumah dan kebun penduduk. Santoso dan gunawan (2000) menyatakan tumbuhan ini mengandung senyawa curcumin, resin, amilum, tanin dan minyak atsiri.

5. Curcuma mangga Val. Backer, C.A dan R.C. Bakhuizen Jr Van den Brink, 1968, Flora of Java, Vol. III, 72.

Nama Daerah $\quad$ : Kunyit temu

Tumbuhan ini berupa herba, timggi 1-2,5 m, memiliki batang semu yang dibentuk pelepah daun, rizoma berbentuk bulat telur dengan anak rizoma yang langsing dan panjang, berwarna kuning. Daun tunggal, berbentuk oblong dan lanset memanjang dengan pangkal runcing, pinggir rata dan ujung meruncing, panjang 40-65 cm dengan lebar 14-21 cm, berwarna hijau. Bunga majemuk bentuk bulir berwarna putih. Jenis ini biasanya ditanam di pekarangan rumah dan kebun penduduk.

6. Curcuma xanthorrhiza Roxb. ; Backer, C.A dan R.C. Bakhuizen Jr Van den Brink, 1968, Flora of Java, Vol. III, 71

Nama Daerah $\quad$ : Temulawak

Tumbuhan ini berupa herba, tinggi 1-2,5 m, memiliki batang semu yang dibentuk pelepah daun, rizoma berbentuk bulat telur dengan anak rizoma yang langsing dan panjang, berwarna kuning,. Daun tunggal berbentuk oblong dan lanset memanjang dengan pangkal runcing, pinggir rata dan ujung meruncing, panjang 40-65 $\mathrm{cm}$ dan lebar 14-21 cm, berwarna hijau dan sepanjang ibu tulang daun berwarna ungu coklat. Jenis ini biasanya ditanam disekitar pekarangan rumah dan kebun penduduk. Marsito (2001) menyatakan tumbuhan ini mengandung senyawa curcumin, mondesmetoksi-curcumin dan minyak atsiri.

7. Etlingera elatior (jack) R.M. sm: Khaw, S.H (2001). The Genus Etlingera (Zingiberaceae) In penin sular Malaysia including A New Species: Garden's Buletin Singapore 53, hal 191-238. Poulsen, A.D (2006). Etlingera Borneo. Hal 111-118.

Basionim : Alpina Elatior Jack., Nicolaia Elatior (Jack) Horan.

Nama Daerah $\quad$ : Sabung

Tumbuhan ini berupa herba, berumpun, aromatis, tinggi 4-7 m, rizoma merah muda, dibawah permukaan tanah, daging rizoma berwarna putih, aromatis. Daun oblong, panjang $55-90 \mathrm{~cm}$, lebar 15-19 $\mathrm{cm}$. Permukaan atas hijau terang dan licin, permukaan bawah daun hijau gelap dan licin. Ujung daun meruncing, pangkal tidak simetris, pinggir rata. Bunga majemuk muncul dari rizoma, berwarna merah muda. Pendunculus panjangnya 1,66-2,32 m, braktea steril pink, braktea fertil merah, brakteola merah, calyx merah, corolla merah, lobus corolla dorsal merah, lobus corolla lateral merah, lip merah, stamen putih, buah masak merah muda, warna biji hitam. 
8. Hedychium coronarum (Koen. Backer, C.A dan R.C. Bakhuizen Jr Van den Brink, 1968, Flora of Java, Vol. III, 65).

Nama Daerah : Suli

Tumbuhan ini berupa herba, berumpun, otomatis, tinggi 0,5-1,28 $\mathrm{m}$, rizoma coklat muda, daging rizoma berwarna putih, aromatis. Daun oblong, panjang 55-90 cm, lebar 15-19 cm. Permukaan atas hijau terang dan licin, permukaan bawah daun hijau gelap dan licin. Ujung daun meruncing, pangkal tidak simetris, pinggir rata. Bunga majemuk muncul pada ujung batang, berwarna hijau. Bunga berwarna putih dan mekar sebanyak 3-4 buah. Pedenculus panjangnya 10$14 \mathrm{~cm}$, braktea steril hijau, braktea fertil putih, brakteola merah, putih kehijauan, carolla putih. Jenis ini tumbuh dipinggir sungai.

9. Kaemferia galanga L., (Backer, C.A dan R.C Bakhuizen Jr Van den Brink, 1968, Flora of Java, Vol.III, 68).

Nama daerah: Ceku

Tumbuhan ini berupa herba dengan rizoma berwarna putih dan aromatis, daun tunggal, menutupi tanah, berkumpul dalam roset, berbentuk elip dengan pangkal membulat, pinggir rata dan ujung meruncing, panjang 6-14 $\mathrm{cm}$ dan lebar 2-8 $\mathrm{cm}$. Bunga majemuk berwarna putih dengan bercak berwarna ungu pada pangkal labelum. Jenis ini biasanya ditanama disekitar pekarangan rumah penduduk. Saantoso dan Gunawan (2000) menyatakan tmbuhan ini mengandung senyawa ester, borneol, kamfer, sineol, etil alkohol dan minyak atsiri.

10. Zingiber cassumnar (Roxb. ; Backer, C.A dan R.C. Bakhuizen Jr Van dn Brink, 1968, Flora of Jaava, Vol. III 44).

Sinonim : : Zingiber purperum Roxb.

Nama Daerah : Kunyit Mlai

Tumbuhan ini berupa herba, tinggi 1-1,5 m, rizoma berwarna kuning muda dan beraroma menyengat. Daun tunggal, memeluk batang, tersusun berselang-seling berbentuk lanset dengan pangkal tumpul, pinggir rata dan ujung runcing, panjang $23-35 \mathrm{~cm}$ dan lebar 2-3 cm. Bunga majemuk muncul dari pangkal batang, berwarna merah muda. Jenis ini ditanam disekitar perkarangan rumah dan kebun penduduk. Wijayakusuma (1996) menyatakan tumbuhan ini mengandung senyawa tanin, flavonoid dan minyak astiri.

11. Zingiber officinale.Rosc.; Backer, C.A. dan R.C. Bakhuizen Jr Van den Brink, 1968, Flora of Java, Vol.III 46.

Sinonim : Amomum zingiber L.

Nama Daerah $\quad$ : Sepedeh / padi-padi 
Tumbuhan ini berupa herba, tinggi 3-10 cm, rizoma bercabang berwarna putih kekuningan. Daun tunggal, memeluk batang, berselang-seling, helaian daun berbentuk pita dengan pangkal runcing, pinggir rata dan ujung meruncing, panjang 15-30 $\mathrm{cm}$ dan lebar 0,8-1,5 cm. Bunga majemuk berupa bulir yang terdapat khusus pada batang yang lebih pendek, dengan daun pelindung seperti sisik berwarna hijau, corolla berbentuk tabung berwarna kuning jingga. Tumbuhan ini biasanya ditanam sebagai tanaman bumbu masakan. Santoso (1998) menyatakan bahwa tumbuhan ini mengandung senyawa kapsaisin, resin, zingiberon dan minyak astiri yang berkhasiat mengobati batuk dan sakit perut.

\section{KESIMPULAN}

Dari hasil penelitian yang telah dilaksanakan dapat disimpulkan bahwa terdapat 11 jenis Zingiberaceae di desa Koto Dua Lama yaitu: Alpinia galanga, Amomum cardamomum, Costus speciosus, Curcuma domestica, Curcuma mangga, Curcuma xanthorrhiza, Etlingera elatior, Etlingera megalocheilos, Etlingera sp., Hedycium coronarium., Hornstedtia elongata, Kaempferia galanga, Zingiber cassumnar, Zingiber officinale dan Zingiber sp. Jenis-jenis Zingiberaceae yang ditemukan ada yang masih tumbuh liar dan ada yang sudah dibudidayakan. Masing-masing jenis yang didapatkan memiliki deskripsi atau karakteristik tersendiri.

\section{DAFTAR RUJUKAN}

Backer, C.A. and R.C. Bakhuizen van den Brink. (1968). Flora of Java, Vol. III. Wolters-Noordhoff N.V. Groningen- The Nederlands.

Holttum, R.E. (1950). The Zingiberaceae of Malay Peninsula. The Garden Buletin Singapore. Singapore.

Khaw, S. H. (2001). The genus Etlingera (Zingiberaceae) in Peninsular Malaysia Including a New Spesies. Gardens' Buletin Singapore.

Larsen et al.. (1999). Gingers of Peninsular Malaysia and Singapore. Natural History Publications (Borneo). Kinabalu. Sabah. Malaysia.

Miquel F.A.W. (1862). Sumatra Zijne Plantenwereld Hare Vootbrengselen Vol. III. Amsterdam.

Newman. M, Lhuillier. A, and Poulsen A.D. (2004). Checklist of The Zingiberaceae of Malesia. Blumea Supplement.

Poulsen, A.D. (2006). Ginger of Sarawak. Natural History Publications (Borneo). Kota Kinibalu.

Rideng Made, I. (1989). Taksonomi Tumbuhan Biji. FKIP Universitas Udayana Singaraja. Bali.

Ridley, N. Henry. (1967). The Flora of Malay Peninsula. L.Reeve \& Co. Ltd London. England.

Singh, G. (2003). Plant Systemics : An Integrated Approach. Science Publisher, Inc: Playmouth.

Sirirugsa, (1999). Thai Zingiberaceae : Spesies Diversity and their Uses. http://www. iupac.org/symposia/procedings/phuket97/sirirugsa.html. 8 Desember 2009.

Smith. R. M. (1981). Zingiberaceae. Synoptic keys to the tribes. Royal Botanic garden Edinburgh. 
Syamsuardi, Tamin. R, dan Nurainas. (2006). Modul Kuliah Taksonomi Tumbuhan Tingkat Tinggi. Jurusan Biologi Univ. Andalas. Padang. (Tidak Dipublikasikan).

Woodland, W. Dennis. (1997). Contemporary Plant Systematics Second Edition. Andrews University Press. Berrien Spring. Michigan. United States of Amerika. 